\title{
A New Rural Social Contract for the Maghreb? The Political Economy of Access to Water, Land and Rural Development
}

\author{
Annabelle Houdret
}

German Development Institute/ Deutsches Institut für

Entwicklungspolitik (DIE)

Annabelle.Houdret@die-gdi.de

\section{Zakaria Kadiri}

Université Hassan II Casablanca and Faculté de Gouvernance et des Sciences

Economiques et Sociales (CRESC, EGE RABAT), Morocco

zakariaa.kadiri@gmail.com

\section{Lisa Bossenbroek}

Faculté de Gouvernance et des Sciences Economiques et Sociales

(CRESC, EGE RABAT), Morocco

lisabossenbroek@gmail.com

\begin{abstract}
The social contract, as the basis of the relations between rulers and populations in the Maghreb region, is highly contested especially since 2011. However, the rural dimension of this phenomenon remains yet under researched. Building on related emerging critical studies, this paper coins the term of a 'rural social contract' and analyses what it embodies. It highlights how the unequal ownership and use of water and land resources contribute to the marginalization of the large majority of rural populations and to their growing discontent. The article argues that three trends currently contribute to the re-articulation of the social contract in rural areas. Firstly, overexploitation and climate change lead to a severe degradation of water and land resources which challenges the established patterns of use and redistribution of these resources. Secondly, agricultural policies focusing on export production and on large entrepreneurs lead to further marginalization of small farmers. Thirdly, the emergence of new rural actors challenge the established social relationships. On the basis of this analysis, the article frames the major challenges, dynamics and characteristic of a newly emerging rural social contract in the Maghreb.
\end{abstract}




\section{Keywords}

Arab Spring - Maghreb - Morocco - Tunisia - Algeria - water - land - agriculture social contract

\section{Introduction}

The presumed stability in the Maghreb before 2011 was based on a so-called 'social contract,' or an implicit agreement between rulers and populations. The population expected their rulers to redistribute the gains from exploiting natural resources or from other economic activities and promote socio-economic development. In exchange, rulers expected their populations to be loyal in a context of very limited (if at all) democratic governance, strong elite capture, fear and coercion. While revenues from oil and gas exploitation secured the economic basis of this social contract in many states of the Middle East and Northern Africa (MENA), ${ }^{1}$ the Maghreb states ${ }^{2}$ - with the exception of Algeria instead relied on benefits from other economic activities such as agriculture. The inability to continue to fulfill the terms of this social contract due to significant economic restrictions and rising popular discontent, combined with severe governance deficits in terms of social justice and economic development, are considered to be major causes of the so-called 'Arab Spring.'3

The notion of the 'social contract' and its underlying political economy have been extensively used to characterize and analyze the socio-political and economic relations in often autocratic regimes in the MENA region. ${ }^{4}$ Its rural dimensions, however, have received much less attention, with the exception

1 Steven Heydemann, ed., Networks of Privilege in the Middle East: The Politics of Economic Reform Revisited. (London, Palgrave, 2004); Raymond Hinnebusch, "Change and Continuity after the Arab Uprising: The Consequences of State Formation in Arab North African States," British Journal of Middle Eastern Studies 42, no. 1 (2011): 12-30.

2 These countries are in the focus of this paper.

3 Richard Javad Heydarian, "The Economics of the Arab Spring," Foreign Policy In Focus, April 21, 2011, http://fpif.org/; Paul Aarts et al., From resilience to revolt: making sense of the Arab Spring (Amsterdam: University of Amsterdam, 2012), 117; Gonzalo Escribano, "A Political Economy Perspective on North Africa's Transitions" (Working Paper 3, Real Instituto Elcano, 2013); Mounia Bennani Chraibi and Mohamed Jeghllaly, "La dynamique protestataire du Mouvement du 20 février à Casablanca," Revue Française de Sciences Politiques 62 (2012): $867-94$.

4 Heydemann, Networks of Privilege in the Middle East; Aarts et al., From Resilience to Revolt; Escribano, "A Political Economy Perspective on North Africa's Transitions." 
of a few inspiring critical scholarly works focusing in particular on Tunisia and Egypt. ${ }^{5}$ The 'rural social contract' has its own very specific characteristics which differ from the general social contract: its economic basis relies on access to natural resources and the socio-political networks determining their distribution are strongly influenced by the colonial legacy. In this case, the 'contract' mainly consists in the redistribution of water and land resources (including in some cases access to agricultural value chains) by national to local elites - and, to a more limited extent, to local populations - in exchange for their loyalty. Historically, control over water and land by a small elite group has played an important role in consolidating the central state's authority over the sometimes rebellious countryside. ${ }^{6}$

The rural social contract persists in the Maghreb countries and is under constant (re-)negotiation between the state, elites and various rural actors. The main reason for the current changes in the contract is the erosion of its economic and socio-political conditions which form the basis of the mutual arrangements between the rulers, the elites and the populations.

Against this background, we analyze in this article (1) the characteristics and the establishment of the rural social contract and (2) the reasons for the decline of the very basis of this contract, which are (a) over-exploitation of natural resources (mainly water and land) coupled to climate change which have challenged established patterns of resource use and subsequently the distribution of benefits from their exploitation; (b) agricultural policies focusing on large agricultural entrepreneurs that further enhance the already strong socio-economic marginalization of small farmers; and (c) the emergence of new rural actors, in particular rural young people but also new agricultural entrepreneurs and investors who challenge established social relationships.

The upheavals that have occurred in many Arab countries since 2011 have clearly questioned the legitimacy of existing arrangements between rulers and populations and left the social contract in a state of flux. In the Maghreb's rural areas, the economic basis of the rural social contract was based on the strategic allocation of water and land to political elites. Now, however, this system faces severe ecological and social constraints that threaten its socio-economic basis. For example, the degradation and overuse of natural resources diminishes

5 Maria Cristina Paciello et al., Reversing the Vicious Circle in North Africa's Political Economy: Confronting Rural, Urban, and Youth-Related Challenges, (Washington, DC: The German Marshall Fund of the United States, 2012).

6 John Waterbury, The commander of the faithful: the Moroccan political elite: a study in segmented politics, (Weidenfeld \& Nicolson, 1970), Remy Leveau, Le fellah marocain, défenseur du thrône, (Paris: Presses de Sciences Po, 1976). 
the overall quantity to be distributed, further increasing the competition over resource access and control. Large-scale farmers often compete on unequal terms, with family farmers - in particular small ones - not having the same financial means or political support. As a result they often rely on unsecure access and control over resources to sustain their livelihoods. Moreover, rural areas often remain marginalized in national development strategies. In Morocco for instance, despite the fact that rural areas have drastically changed over the last decades many still face poor education, healthcare facilities and limited transport infrastructure and relatively lower incomes. ${ }^{7}$

Although the revolts that have occurred since 2011 have primarily manifested themselves in urban centres and cities, dissatisfaction in rural areas has also played a significant role in this context, as mentioned by various scholars. ${ }^{8}$ Alongside the aforementioned structural problems, recent years have been marked by economic crisis, rising living costs and poor employment prospects for the younger population. Life has become significantly more difficult for rural residents. It is telling that the revolution in Tunisia began with the self-immolation of an unemployed vegetable seller in the politically-neglected town of Sidi Bouzid. Two years after the overthrows in Egypt and Tunisia, however, observers have noted that the population in the rural regions and their concerns continue to be excluded from the political transition process. ${ }^{9}$

In what follows, we first explain the notion and the evolution of the 'rural social contract' in the Maghreb region. The second part focuses on the three above-mentioned trends contributing to the erosion and renegotiation of the old social contract's basis. In the conclusion, we summarize our key findings, reflect on the use of the concept of the rural social contract beyond the Maghreb region and discuss further research needs.

This article is based on extensive field research on water, land, agriculture and governance issues conducted by the three authors mainly in Morocco, but also in Tunisia and Algeria since 2005. To support our analysis, we also draw on examples from Egypt, whose agrarian situation is similar to that of Morocco

7 James N. Sater, Morocco: Challenges to tradition and modernity (Routledge: New York, 2016); Zakaria Kadiri and Fatimaezzahra El Farah, L'agriculture et le rural au Maroc, entre inégalités territoriales et sociales (Blog scientifique Farzyates/Inégalités du Centre Jacques Berques Rabat 2013); Lisa Bossenbroek, Behind the veil of agricultural modernization : gendered dynamics of rural change in the Saiss, Morocco (Wagenigen University: Den Haag 2016).

8 Mohamed Elloumi, "La Révolution Tunisienne: Ruralité vs. Urbanité. Quelques réflexions," La lettre de l'IRMC 8 (2012).

Ray Bush, Family farming in the Near East and North Africa, FAO Working Paper 151 (December 2016).

9 Ibid.; Paciello et al., Reversing the Vicious Circle in North Africa's Political Economy. 
and Tunisia. Conceptually, this article contributes to the emerging debate on the role of the rural regions in re-negotiating redistributive relations ${ }^{10}$ as well as to the ongoing debate on a new social contract in the MENA region. It aims to shed light on how resource use in light of environmental degradation and climate change, export oriented agricultural policies and the emergence of new rural actors together contribute to the erosion of the old social contract's economic and socio-political basis, and where elements of an emerging new social contract can be observed.

\section{The Rural Social Contract in the Maghreb Countries}

This section introduces the concept of the 'rural social contract'. We explain the key characteristics of the 'social contract' in the countryside, which consists of the monopolization of access to water and arable land for agricultural production by established elites who, in turn, secure the central governments' influence in rural areas. We further illustrate how these unequal redistributive relations are rooted in the political history of the Maghreb countries.

The political economy of Arab states was long based on what has been labeled by different researchers as a 'social contract' between rulers and their populations. "1 The term dates back to the ancient Greek philosophers and was later developed by Hobbes, Rousseau, Locke and others. ${ }^{12}$ Hobbes uses the term to describe a contractual means of overcoming the presumed natural condition of mankind characterized by war of all against all. The social

10 Alia Gana, "The Rural and Agricultural Roots of the Tunisian Revolution: When Food Security Matters", International Journal of Sociology of Agriculture and Food, Research Committee on Sociology of Food and Agriculture 19, no. 2 (2012); Habib Ayeb and Ray Bush, "Small Farmer Uprisings and Rural Neglect in Egypt and Tunisia," Middle East Report 272 (2012).

11 Steven Heydemann and Reinoud Leenders, "Authoritarian Learning and Authoritarian Resilience: Regime Responses to the 'Arab Awakening," Globalizations 8, no. 5 (2011); Mehran Kamrava, "The Rise and Fall of Ruling Bargains in the Middle East" in Beyond the Arab Spring: The Evolving Ruling Bargain in the Middle East, ed. Mehran Kamrava (Oxford: Oxford University Press, 2014); Shanta Devarajan and Lili Mottaghi, Towards a New Social Contract (Washington, DC: World Bank, 2015); Hedi Larbi, Rewriting the Arab Social Contract. Toward Inclusive Development and Politics in the Arab World (Cambridge: Middle East Initiative, 2015).

12 Fred D'Agostino, Gerald Gaus, and John Thrasher, "Contemporary Approaches to the Social Contract," The Stanford Encyclopedia of Philosophy, December 20, 2011, https://plato. stanford.edu/. 
contract is a formal or informal agreement that regulates the relationship between the dominant political authority and society and underpins the moral and legal legitimacy of a political regime. The contract materializes through a transaction or bargain between the state and society. With respect of the Arab states, the term 'social contract' has been used to describe the prevailing arrangement between often oil-rich countries distributing the gains from the exploitation of their natural resources in exchange for individuals' acquiescence to authoritarian rule, strong elite capture, fear and coercion. ${ }^{13}$ Besides the economic relations, the social contract also shaped social and political relationships to the point that it 'developed and spread throughout the economy and society, influencing practices, minds, culture and morality'. ${ }^{14}$ As a result, these relationships are dominated by different forms of clientelism such as informal payments for obtaining preferential treatment with administrative procedures or access to economic opportunities or natural resources. This system severely undermines fairness and equality of opportunities and also contributes to the erosion of administrative systems and overall state performance. ${ }^{15}$ Some arrangements of the social contract have significantly contributed to job-creation (for instance through the creation of public employment in oversized state administrations) and ensured the loyalty of elites, public company managers and rent-seeking entrepreneurs. However, the contract has failed to deliver prosperity and social justice for the majority of the people. ${ }^{16}$ Revenues from oil and gas exploitation as well as from foreign aid were the 'classical' economic basis of the Arab rentier states and their social contracts. Over time, the basis of the contract broadened and today it consists of 'an integrated institutional system that is capable of extracting rent from any economic process, whether it relates to investment, production or trade. ${ }^{17}$

As Al-Razzaz mentions, the economic basis of the 'social contract' does not only rely on oil or gas-revenues. ${ }^{18}$ Especially in oil-poor countries such

\footnotetext{
13 Heydemann, Networks of Privilege in the Middle East; Aarts et al., From resilience to revolt; Escribano, "A Political Economy Perspective on North Africa's Transitions."

14 Ibid., 4.

15 Brixi, Hana; Lust, Ellen; Woolcock, Michael. 2015. Trust, Voice, and Incentives : Learning from Local Success Stories in Service Delivery in the Middle East and North Africa. Washington, DC: World Bank.

16 Adeel Malik and Bassem Awadallah, "The Economics of the Arab Spring," Middle East Insights.

17 Omar M. Al-Razzaz, The Treacherous Path Towards a New Arab Social Contract (Beirut: Issam Fares Institute for Public Policy and International Affairs, 2013).

18 Ibid.
} 
as Morocco and Tunisia, access to water and land for agricultural or industrial production is significant not only for rural livelihoods but also for economic elites seeking business opportunities. However, water and fertile land are scarce in these countries and competition over their control is therefore high - this leads to a strong politicization of resource access and allocation. Historically, wherever there has been irrigated agriculture, local power structures have monopolized control over resources. ${ }^{19}$ Today, the increasing degradation and overuse of water and land even reinforce competition, politicization and rent-seeking behavior of elites. Notwithstanding this, agriculture has developed considerably over the past decades, particularly in Maghreb countries such as Tunisia, Morocco or Egypt that do not boast extensive oil and gas reserves. Agriculture has since become a key driver of economic growth and employment. In recent years, however, rising demand for water and arable land has diminished the availability of resources due to resource overexploitation. At the same time, irrigated agriculture has heightened competition for land and water, with water-intensive cash crops placing increasing demands on the local climate.

In Morocco, Tunisia and Algeria, agriculture contributes 16.9, 10 and 10 percent respectively to the GDP of these countries. Moreover, the sector is a key employer in some of the countries, employing around 40 and 19 percent of the population respectively in Morocco and Tunisia and 10.5 percent of the population in Algeria. ${ }^{20}$ However, the economic relevance of the sector is even greater than it appears. In rural areas, agriculture employs up to 80 percent of the population; ${ }^{21}$ this percentage is even higher when the widespread 'informal' wage labour is taken into account. In more favourable climate conditions, it can also make a more significant contribution to the overall Gross Domestic Product (GDP). In Morocco, for example, a year of significant rainfall can raise the agricultural share to 21 percent of GDP, whereas a drought year can reduce it to 14 percent. Studies have shown that this share can be even twice as high if the whole value-chain including the activities preceding and following production are taken into account. ${ }^{22}$

\footnotetext{
19 Ibid.

20 Food and Agriculture Organization, FAO Statistical Pocketbook 2015 World Food and Agriculture (Rome, 2015).

21 Agence pour le Développement Agricole, Le Plan Maroc Vert (Rabat: Ministère de l'Agriculture, 2010).

22 Alberto Valdés and William Ellis Foster, "Reflections on the Role of Agriculture in ProPoor Growth," World Development 38, no. 10 (2010): 1362-1374.
} 


\section{Rooting the 'Rural Social Contract' in History}

The strategic instrumentalization of water and land resources in the Maghreb dates back to the colonial times. During this time, the different colonial powers in Morocco, Algeria and Tunisia or Egypt invested in the expansion of agriculture in order to serve their own markets, establishing medium-sized and large companies run by their own nationals. The contracts to develop the irrigation infrastructure, including the cost and material-intensive dams, primarily benefited domestic companies such as French state construction companies in the case of Algeria and Morocco. ${ }^{23}$ In the postcolonial years, the significant expansion of the irrigation sector (as in Morocco), the construction of extensive water transfer infrastructure between regions (as in Tunisia) and what were then enormous dam building projects (as in Egypt) led to the creation of a so-called 'hydrocracy' This is how Molle refers to the still-influential interest groups of local and international construction companies, operators of hydrological infrastructure and development banks that continue to promote the development of expensive infrastructure out of financial interest. ${ }^{24}$ The colonial regimes established large-scale irrigated areas, favouring loyal colonial settlers and national elites in the distribution of water and fertile land. In this manner, they established a power base to control the rural population. ${ }^{25}$ For example in the case of Morocco, landownership towards the end of the French protectorate clearly reflected unequal power relations. As explained by Swearingen, ${ }^{26}$ by the end of the protectorate \pm 13 percent of the arable land was in hands of 5900 Europeans and \pm 4 percent belonged to 1700 Moroccans who owned the best lands with the average size of a farm being 170 hectares. ${ }^{27}$ In contrast, the remaining 83 percent of agricultural lands, regarded as 'traditional land,' belonged to 1.4 million Moroccan farming families. These numbers do not capture the 500,000 families owned less than 0.5 hectares of land or owned no

23 Jacques Pérennès, L'Eau et les Hommes au Maghreb - Contribution à une politique de l'eau en Méditerrannée, (Paris: Karthala, 1993).

24 François Molle, "Politiques Agraires et Surexploitation de l'Eau au Maghreb et au Machrek," in Pouvoirs, sociétés et nature au Sud de la Méditerranée, ed. Tarik Dahou et al. (Paris: INRAT/IRD/Karthala, 2011), 109-130.

25 Leveau, Le fellah marocain; Pérennès, L'Eau et les Hommes au Maghreb.

26 Will D. Swearingen, "Terre, Politique et Pouvoir au Maroc," Revue de l'Occident Musulman et de la Méditerranée 45 (1987): 41-54.

27 Lisa Bossenbroek and Margreet Zwarteveen, “'One Doesn't Sell One's Parents': Gendered Experiences of Shifting Tenure Regimes in the Agricultural Plain of the Sais in Morocco" in Global Trends in Land Tenure: Gender Impacts, ed. Caroline S. Archambault and Annelies Zoomers (London and New York: Routledge, 2015), 152-169. 
land at all, as well as the landless farmers who often worked as laborers on the colonial farms. $^{28}$

After independence, the distribution of the lands that previously belonged to foreigners remained a sensitive and long unresolved issue. In the meantime, large proportions of private lands that belonged to foreign settlers were sold to elites or were confiscated by the state. In the case of Morocco, 70 percent of the land of the 1 million hectares that were retrieved after independence fell into the hands of the state or the elite and only 30 percent were redistributed in the early 1960 s and 1970 s to landless and small farmers. ${ }^{29}$ Similar trends can also be observed in Algeria and Tunisia, ${ }^{30}$ where, like Morocco, partial land reforms were initiated 'to tame the countryside and prevent a rural exodus' but favoured elites (so-called 'notables') in practice. These elites delivered political loyalty by relaying local information to the government and strengthening the local position of those in power. ${ }^{31}$ In Morocco for example, the government rewarded pro-monarchy actors in rural strongholds with land. ${ }^{32}$

Historical inequalities in control over and access to the main productive resources persist today. They manifest themselves in socio-economic disparities and often inadequate infrastructure in rural regions. Small farmers are more exposed to difficulties to secure their livelihoods and the expansion of exportoriented, large-scale agriculture primarily benefits an economic and political elite (see next section). ${ }^{33}$ As a case in point, the rural population of Tunisia never benefitted from the same advancements in transportation, education and healthcare infrastructure as those in the towns and coastal regions. ${ }^{34}$ Recent efforts to increase the involvement of the private sector in irrigation

28 Ibid., 43.

29 Negib Bouderbala, "La Lutte contre le Morcellement au Maroc: Un Thème Idéologique," in Terres méditerranéennes. Le morcellement, richesse ou danger? ed. Anne-Marie Jouve (Paris/Tunis : Karthala-Ciheam, 2001); Paul Pascon, "Interrogations autour de la Réforme Agraire," in La question agraire au Maroc, ed. Negib Bouderbala, Mohamed Chraïbi, and Paul Pascon (Tanger: Éditions Marocaines et Internationales, 1977) 183-200.

30 J. Dresch et al., Réforme agraire au Maghreb: colloque sur les conditions d'une veritable réforme agraire au Maroc (Paris : Francois Maspero, 1963).

31 Zakaria Kadiri and Mostafa Errahj, "Leadership Rural au Maroc, entre Jeunes et Notables," Alternatives Rurales hors série (2015): 56-67.

32 Leveau, Le fellah marocain; Pérennès, L'Eau et les Hommes au Maghreb.

33 Tarik Dahou et al., Pouvouirs, sociétés et n ature au sud de la Méditerranée (Karthala : INRAT-IRD, 2011).

Elloumi, "La Révolution Tunisienne." 
and agricultural production in the form of public-private partnerships have also continued to favour elites. ${ }^{35}$

In sum, this section has shown the historical relevance of the rural dimension of the social contract in the Maghreb region. The post-colonial regimes maintained control of natural resources to secure profitable production conditions for loyal elites who controlled the countryside. The arrangement between those in power and the rural elite consisted of granting access to water and land and control over sales markets in return for political loyalty and profit-sharing. Other parts of society, such as smallholders, had only limited involvement in socio-economic development and were excluded from political participation. In the aftermath of the 'Arab Spring', the social contract is gradually being renegotiated. Beyond the Maghreb countries, these structures are similar in other countries of the MENA region, as analysed inter alia by Francesca de Châtel. ${ }^{36}$ The next section focuses on three key trends that currently contribute to the re-articulation of this contract model.

\section{New Social Contract? Three Trends Explaining the Transformation of the Rural Social Contract}

The strong links between access to land and water for agricultural production and the local political economy detailed above explain why and how some population groups have been marginalized. However, the established patterns of resource use that provide the basis of this contract and their socio-economic and political implications are eroding. Three trends contribute to this erosion: First, the degradation and overuse of already scarce water resources and arable land - combined with the effects of climate change and an ever increasing demand - have considerably restricted resource availability. This limits the amount of natural resources to be redistributed and contributes to the erosion of the economic basis of previous arrangements. Second, agricultural policies such as Morocco's ‘Green Morocco Plan' ('Plan Maroc Vert', hereafter P MV) have further marginalized small farmers and tend to concentrate access to land and water resources in the hands of commercial farms and influential elites. This contributes to the erosion of the socio-political basis of the old social contract,

35 Annabelle Houdret, "The Water Connection: Irrigation, Water Grabbing and Politics in Southern Morocco," Water Alternatives 5, no. 2 (2012): 284-303; Zakaria Kadiri and Mohamed Mahdi, "Eau: une Coordination à Plusieurs Cycles," Economia (2013): 45-51.

36 Francesca de Châtel, Water Sheikhs and Dam Builders, Stories of People and Water in the Middle East (New Jersey: Transaction Publishers, 2007). 
as former elites become less influential, but also to the decline of its economic basis because of the monopolization of resource use. Third, new rural actors and especially young rural leaders have emerged to challenge existing power relations and the position of rural elites. For these elites, access to and control over the main production resources (land and water) are no longer the only sources of power in the rural countryside. Instead, new forms of leadership based on know-how and social networks have emerged, which contributes to transform the socio-political basis of the social contract.

\section{Ecological Degradation and Environmental Change}

As mentioned before, the distribution of water and land has been highly politicised in the agricultural sector, especially since local incomes and food security in rural areas are often directly dependent on access to these resources. As illustrated in what follows, this has an immediate effect upon the sociopolitical stability and legitimacy of political regimes. Resource access and use, the larger political economy as well as networks of privilege form the basis of the old social contract and are now undergoing many changes. The first trend, overexploitation of natural resources, is being aggravated by the increasingly strong impacts of climate change; this contributes to the erosion of the basis of former arrangements in the sense of the social contract. This has contributed to increased competition over and unequal access to these resources. Overexploitation of natural resources is largely practiced by large-scale farmers to irrigate water-intensive cash-scrops and also often becomes the only way for small farmers to survive in the face of threats to their livelihood, in spite of the degradation this causes in the long term. ${ }^{37}$

Overuse and degradation of water and arable land resources have to be considered in their specific regional context. The Maghreb countries are characterised by a semi-arid climate with significant fluctuations in the availability of water and soil fertility. Economic development has placed increasing demands on the already scarce supply of water and agricultural land. The expansion and intensification of irrigated agriculture and tourism, industry, urbanisation and changing lifestyles (water-intensive consumer habits) are increasing the demand for water. Overexploitation and pollution of water resources, as well as the effects of climate change, have further diminished the availability of water resources. Surface water in the form of rivers and lakes has been exhausted. Groundwater resources have also been depleted beyond the point of Tarik Dahou et al. (Paris/Tunis/Marseille: Karthala/INRAD/IRD, 2011), 83-108. 
regeneration due to poorly regulated private wells and boreholes. ${ }^{38}$ In some confined aquifers, particular in the Saharan groundwater context, the water tables have dropped as much as $100 \mathrm{~m}$ in the past 20 years. ${ }^{39}$ Groundwater is increasingly becoming a source of growing inequalities, with farmers having not sufficient financial means facing high risks of losing access to groundwater and therefore their livelihoods. Rising pumping and drilling costs have also created inequalities in access to groundwater. ${ }^{40}$

Water consumption in the majority of countries in the Maghreb region, as well as in North Africa in general has already exceeded the rate of renewal for the resource. ${ }^{41}$ This has negative consequences on water quality and availability, which in turn affects soil fertility as well as health and prosperity. The World Bank already estimates the economic effects of the degradation of water resources in Egypt, Jordan, Lebanon and Morocco to be as high as 1 percent of the GDP. ${ }^{42}$ The situation is similar with regard to the per capita availability of water, which is frequently used to measure the scarcity of the resource. However, the national average often disguises significantly worse situations in specific regions, seasons, years or for specific population groups.

Climate change further exacerbates this situation with higher average temperatures, lower rainfall and more frequent periods of drought. ${ }^{43}$ In the future, rising sea levels may cause increased salinization in coastal waters, which are often used for agricultural production. Estimates of the impact of climate change on the GDP of the MENA states vary greatly. In Tunisia, for example,

38 M. Kuper et al., "Liberation or Anarchy? The Janus Nature of Groundwater on North Africa's New Irrigation Frontier," in Integrated Groundwater Management, ed. Anthony Jakeman et al. (Cham: Springer International Publishing, 2016), 583-615; Lisa Bossenbroek, Marcel Kuper and Margreet Zwarteveen, "Sour Grapes: Multiple Enclosures of Ground Water in the Region of the Sais in Morocco," in Drip Irrigation: Untold Stories of Efficiency, Innovation \& Development, ed. J.P. Venot, M. Kuper and M. Zwarteveen (Earthscan, forthcoming).

39 Ministère des Ressources en Eau, Note sur l'activité de l'hydraulique agricole (Algiers, 2011).

$40 \quad$ Bossenbroek, et al., "Sour Grapes."

41 United Nations, Managing Water under Uncertainty and Risk, World Water Development Report 4, Volume 1 (Paris: UnesCO, 2012); Kuper et al., "Liberation or anarchy?".

42 Dorte Verner, Adaptation to a Changing Climate in the Arab Countries: A Case for Adaptation Governance and Leadership in Building Climate Resilience (Washington, DC: World Bank, 2012).

43 Dorte Verner, Adaptation to a Changing Climate in the Arab Countries: A Case for Adaptation Governance and Leadership in Building Climate Resilience. 
estimates of future losses range from relatively slight effects of up to - 0.41 percent to 6 percent as estimated by the World Bank. ${ }^{44}$ These losses primarily affect the agriculture and tourism sectors, although the indirect consequences are felt far beyond these areas. As with other estimates of the repercussions of climate change, these assessments are highly contentious due to the high degree of uncertainty involved. ${ }^{45}$ Regardless of the exact amount of GDP lost, the degradation of water and land resources will only increase as a consequence of climate change and human overuse. This will have particularly negative effects on poor rural populations, who are more vulnerable to the effects of climate change. Their income mostly derives from sectors such as agriculture, which are susceptible to climate change, and is disproportionately spent on (increasingly expensive) food compared to other groups. ${ }^{46}$

As in other parts of the world, water policies in the Maghreb countries are only slowly adjusting to these changing circumstances. As mentioned by $\mathrm{Ku}-$ per ${ }^{47}$ with regard to groundwater use and overexploitation, the awareness of the coming groundwater crisis has become a common discourse. Until now, however, this has not lead to better management of groundwater use in the Maghreb region. ${ }^{48}$ Indeed, until just a few years ago, augmenting supply by building dams, pumping groundwater or, more recently, building desalination plants was at the centre of national and transboundary water policies.

In view of the almost at capacity use of the available surface water resources, widespread overuse of underground aquifers, and still increasing demand, only more efficient water governance and demand management may help mobilizing additional water resources. ${ }^{49}$ This will complicate the already highly

44 Francesco Bosello and Fabio Eboli, "Economic Impacts of Climate Change in the Southern Mediterranean," MEDPRO Technical Report 25; Verner, Adaptation to a Changing Climate in the Arab Countries.

45 To a certain extent this uncertainty is doubled, as the margin of error of the projections may increase considerably: on the one hand there are uncertainties with regard to climate change in general and its local effects in particular; on the other hand the forecast social developments and associated environmental trends (including demographic trends, ecological effects, the development of natural resource, the ability to adapt ...) are unclear. The combination of these two uncertainty factors potentiates itself and renders reliable quantitative forecasts largely impossible.

46 Verner, Adaptation to a Changing Climate in the Arab Countries, 25.

47 Kuper et al., "Liberation or Anarchy?".

48 Ali Hammani et al., "Paving the Way for Groundwater Management: Transforming Information for Crafting Management Rules," Irrigation and Drainage 58 (2009): 240-51.

49 N. Vijay Jagannathan, Ahmed S. Mohamed and Alexander Kremer, Water in the Arab World: Management Perspectives and Innovations, (Washington, DC: World Bank, 2009). 
politicized process of governing and distributing resources in the region. Allocating scarce resources to the different sectors (agriculture, tourism, industry, households...), between individual regions of a country and also within specific users in a same area (between large-scale and small-scale farmers, tourism investors and farmers, etc.) or between different countries (in the case of transboundary watercourses such as the Euphrates-Tigris, the Nile or joint underground aquifers) may also generate conflict in the future. ${ }^{50}$ Moreover, demand management strategies at national and local levels, such as the pricing of water services or involvement of private companies in water supply for households and agriculture may also create tension if they are not socially and ecological sustainable.

In addition to creating high environmental and economic costs, the decreasing availability of water and arable land restricts the options available to politicians and elite networks. Where there are fewer resources to distribute, restrictions in access and benefits are inevitable. This not only challenges established patterns of resource use, but also affects related socio-political relations. Farmers with less financial means, and small family farms, who rely on public water distribution, or on wells, may be affected by decisions to privilege the provision of water to households in urban areas. Entrepreneurial farmers and large farmers like some of those in Southern Morocco are better placed to handle these challenges, since they are able to invest in deep drilling that can access water when the small farmers' wells dry out. ${ }^{51}$ This may force some farmers to abandon farming altogether and to move to the city or to sell their labour force to secure their survival.

\section{Agricultural Policies Reinforcing Marginalization}

The second factor contributing to the (re-)negotiation of the rural social contract is agricultural policies that favour a small minority of financially strong and politically influential agricultural entrepreneurs while marginalizing the majority of small/family famers. The effects of this trend on small farmers have been aggravated by land concentration and rising living costs. The example of

5o Ibid.; United Nations, Managing Water under Uncertainty and Risk.

51 Elhassan Elmahdad, Al maa oua al inssan fi haoud souss: moussahama fi behat nidam-hyro janoub-atlas almaghreb, L'Eau et l'Homme dans le Bassin du Souss: Contribution à l'Étude d'un Hydro-Système Sud-Atlanique Marocain (Agadir, Morocco: FLSH, 2003); Annabelle Houdret, Wasserkonflikte sind Machtkonflikte. Ursachen und Lösungsansätze in Marokko, (Wiesbaden: VS Verlag für Sozialwissenschaften, 2010). 
Morocco is given here as the most prominent case but trends in Tunisia and Egypt suggest similar developments. ${ }^{52}$

Morocco's agricultural policy, the PMV, implemented since 2008, illustrates the shifting priorities in Morocco's agricultural policies and is emblematic of similar choices in other Maghreb countries. The plan has two main components, called 'pillars.' The first pillar aims to develop a competitive agricultural sector based on high productivity and high added value. This pillar has received the most funding and attention to date. ${ }^{53}$ It relies on the emergence and strengthening of private investors and entrepreneurial farmers. These new actors often benefit from subsidies to develop the agricultural sector. The second pillar has less financial support and aims to support 'solidarity' agriculture as well as small and medium scale marginalized farmers. The PMV purports to overcome the dualist vision of the Moroccan agricultural sector. According to the policy's proponents, "this new strategy should break with the past and the traditional paradigm of opposing a modern sector to a social sector."54 In reality, however, this policy reproduces the duality in the agrarian sector by dividing its strategy into two pillars.

The expansion of export and cash crop-oriented agriculture as a goal of the PMV and other regional agricultural policies enhances the marginalisation of small-scale farmers who represent the majority and most of whom are unable to adopt this production model for a variety of reasons. ${ }^{55}$ Policies promoting highly intensive and productive agriculture also have significant effects on the environment and contribute to the degradation and overexploitation of water and land resources. This, in turn, leads to increasing inequalities and rising tensions over access to these resources. ${ }^{56}$

Agricultural policies in the Maghreb do not, as they did in former times, centre primarily on the promotion of rural development and national food

$52 \quad$ Ibid.

53 For a critical analysis see Najib Akesbi, "Une Nouvelle Stratégie pour l'Agriculture Marocaine : Le Plan Maroc Vert," Revue New Medit 11, no. 2 (2012): 12-23; Kadiri and El Farah.

54 Ministère de l'agriculture et de la pêche maritime, "Les Idées Forces," http://www.agriculture.gov.ma/pages/idees-forces.

55 François Molle, "Politiques Agraires et Surexploitation de l'Eau au Maghreb et au Machrek," 109-130.

56 Houdret, "The Water Connection"; O. Bessaoud, "Les politiques de développement rural en Méditerranée: des évolutions très contrastées entre le Sud, l'est et le nord de la Méditarranée," Options Méditarranéennes A no. 72 (2006): 27-31. 
security. Instead, they focus on supporting large agricultural entrepreneurs in order to boost the national economy. Some of these entrepreneurs, however, need to keep their ties with the rural 'notables' (the traditional local elites). The latter are themselves undergoing a process of change. Today, they are a diverse group consisting of traditional authorities, investors and entrepreneurs who have adapted themselves to, and benefit from, the new development model..$^{57}$ Investors performing and engaging in an intensive, modern and productive way of farming have profited of new land tenure relations. Large portions of productive lands have become available through land privatization and sales or private public partnerships. ${ }^{58}$

Political decision-makers have approached the agricultural sector like any other economic branch, operating under the assumption that increased investment will lead to increased productivity. ${ }^{59}$ Nevertheless, the experiences of the past 50 years have proved that this perspective is too narrow to encompass the complexity of the sector and its multiple socio-economic functions. In short, it is problematic both in terms of productivity and equity.

Such policy trends and narratives further concentrate land in the hands of a few and contribute to increasing marginalization of small farmers in the Maghreb countries. The distribution of land is highly unequal within the region: in Tunisia, for instance, 53 percent of the farmers cultivate just nine percent of the arable land, for example. ${ }^{60}$ In the Maghreb as a whole, an average of two thirds of farms are smaller than five hectares in size, in Morocco this share raises to 71 percent. ${ }^{61}$ This is joined by the fact that the already small parcels of arable land are frequently divided up amongst multiple farmers, for

$57 \quad$ Kadiri and Errahj, "Leadership Rural au Maroc.”

$5^{8}$ Mohamed Mahdi, "Devenir du Foncier Agricole au Maroc. Un Cas d'Accaparement des Terres" New Medit, A Mediterranean Journal of Economics, Agriculture and Environment 13, no. 4 (2014): 2-10.

59 Ministère de l'Agriculture et de la Pêche Maritime, "Plan Maroc Vert: Premières Perspectives sur la Stratégie Agricole” (slideshow presentation, Salon International de l'Agriculture de Meknès, April 22, 2008).

$60 \quad$ Ibid.

61 Akka Ait El Mekki, "L'Agriculture, l'Agro-Alimentaire, la Pêche et le Développement Rural au Maroc," in Les agricultures méditerranéennes : analyses par pays, ed. M. Allaya (Montpellier: Centre International de Hautes Etudes Agronomiques Méditerranéennes, 2008), 1-36; Etienne Montaigne and Omar Bessaoud, "Quelles Réponses au Mal-Développement Agricole? Analyse des Politiques Agricoles et Rurales Passées et Présentes," in Perspectives des politiques agricoles en Afrique du Nord, ed. Sébastien Abis et al. (Paris: CIHEAM, 2009), 51-91. 
example due to laws of succession. ${ }^{62}$ For these farmers, the size of arable land has a direct impact on income since with the exception of often badly paid and insecure seasonal work on the large farms there is often little other opportunity to find work. These smallholders, who typically make up the majority of the rural population, have been particularly affected by the deterioration in living standards. In the case of Morocco, certain land policies implemented over the last two decades have further exacerbated the unequal distribution of land resources. For example, in 2004 the Moroccan State offered public private partnerships on land formerly under state control to private actors for a period of maximum of 99 years. ${ }^{63}$ Only investors who can establish productive and modern farm projects are eligible to these concessions. Similar observations have been made regarding the public-private partnerships implemented and subsidized by the PMV. ${ }^{64}$ Moreover, in 2006 the state decided to privatize the land of the former socialist inspired collective state cooperatives. ${ }^{65}$ In some cases, this forced farming families to sell their lands, with some becoming labourers on the land that they formerly owned, while others move out of agricultural all together and move to the city. Since then, the land prices have risen dramatically. In some regions, land is only affordable for a select number of 'farmers,' who often turn out to be doctors, lawyers, or businessmen.

\section{The Emergence of New Rural Actors Challenging the Established Political Economy}

The third trend contributing to the erosion of the old social contract's basis is the emergence of new rural actors and especially of young rural leaders who are challenging the existing power structures. As mentioned above, access to and control over land and water were the main origins of influence and power in rural areas in the past. These factors are being replaced by new sources and forms of leadership, which have brought about changes to the established social order.

In the Maghreb countries, the composition of the elites who have benefitted from agriculture has undergone significant changes in the past 20 years.

62 In Tunisia just 48 percent of rural plots are tended by just one farmer, 26 percent by two farmers and the remainder by more individual farmers. See World Food Programm, "Secondary Data Analysis on the Food Security Situation in Tunisia," (working paper, Food and Agriculture Organization, Rome, 2011).

63 Mahdi, "Devenir du Foncier Agricole au Maroc."

64 Bessaoud, "Les Politiques Publiques de Modernisation Agricole au Maghreb."

65 Bossenbroek and Zwarteveen, "One Doesn't Sell One's Parents." 
It is no longer the local-level elites (called 'notables') who need to maintain their relationship with the public authorities in return for particular privileges.

Other economic and political elites have begun investing in this sector who are more independent from the traditional, Makhzen-affiliated political establishment (in case of Morocco). ${ }^{66}$ These include businessmen for whom food production represents just one of several portfolios, members of parliament looking to invest their money in export fruit and vegetables, and an economic elite comprising companies of the ruling apparatus (such as the Moroccan royal family or the Egyptian army). This evolution has also been favoured by the internationalisation of trade. Nowadays, landowners and traders directly export abroad and have built up their own business-networks. Professional large-scale farms use their know-how and considerable technical and financial means to conduct what is as a rule highly-intensive farming, acquiring a position of supremacy in the production and marketing of premium (export) production.

Besides the emergence of new agricultural business elites, the case of Morocco also points to another increasingly influential group consisting of young people who are often educated and play a key role in the re-negotiation of the socio-political order. The advent of social uprisings in the Maghreb countries in 2011 and the various studies focussing on young people in the post 2011 socio-economic context illustrate their critical collective awareness of the existing power relations. ${ }^{67}$ However, neither the agrarian policies of the three Maghreb countries nor policy makers specifically consider and address this group. Nevertheless, young people living in rural areas in the Maghreb region are carriers of innovations and projects, are mobile and have acquired particular know-how through schooling, practical trainings and different farming experiences. ${ }^{68}$ They actively contribute to, and engage in the development of their territory, in particular in the dynamic and potentially lucrative sector of

66 Until the end of the protectorate, the Makhzen referred to the apparatus of state domination and power. Until the protectorate the Makhzen used to denote a bureaucratic establishment founded on the court surrounding the Sultan, his administration and his local representatives. The term is still used today and refers to a mode of governance that determines the relationship between the ruler and those who are ruled (Mohamed Tozy 1991) 'Les enjeux de pouvoir dans les "champs politiques désamorcés” au Maroc', In: C. Michel (Eds.) Changements politiques au Maghreb, (Paris: Editions du CNRs, 1991).

67 Béatrice Hibou, "Le mouvement du 20 février. Le Makhzen et l'antipolitique: L'impasse des réformes au Maroc" Dossiers du CERI (2011).

68 Lisa Bossenbroek, Jan Douwe van der Ploeg, and Margreet Zwarteveen, "Broken Dreams? Youth Experiences of Agrarian Change in Morocco's Saïss region," Cahiers Agriculture 24 (2015): $342-348$. 
irrigated agriculture, which benefits from public support. ${ }^{69}$ These young people do not hesitate to enter into negotiations with the state to obtain subsidies. By doing so, they benefit from the public institutions' logic primarily targeting 'educated' and 'modern' farmers.

In spite of the diverse trajectories of rural young people and their agricultural context, comparative analyses conducted in Tunisia, Algeria and Morocco reveal that there is a common motivation for developing small agricultural enterprises. These enterprises substantially differ from the activities of the former generation in terms of modes of production, choice of crops, commercialization and social organization. ${ }^{70}$

Among this category of rural young people new forms of leadership are emerging, which challenge the rural socio-political power that was so far dominated by notables. These young leaders are not anymore, as it was the case in the past, successors of the established notables' big families. Instead, they have become leader because of their particular competences. They are well educated and often acquired their education in urban regions and are now returning to their village of origin, often because they lack professional opportunities elsewhere. ${ }^{71}$ Besides their involvement in agriculture, they are also wellrecognized local leaders who have initiated or are involved in development projects and different associations and cooperatives. Today, they participate in the communal elections. Yet, despite their prominence in non-governmental organizations (NGOS) or local cooperatives, they do not yet have sufficient experience, networks and financial means to challenge the "traditional" notables on the political playground..$^{72}$ However, they succeeded to enter in the municipal administration and play a key role in the daily life through their presence in

69 Hichem Amichi, Zakaria Kadiri, Sami Bouarfa, Marcel Kuper, "A Generation Looking for Opportunities and Recognition: Young Rural People and Their Pathways into Irrigated Agriculture in North Africa," Cahiers Agriculture 24 (2015): 323-329.

70 Anne Laure Collard, Jeanne Riaux, Sylvain Massuel, Marwa Raïssi and Julien Burte, "Why Shouldn't We Be Like the Farmers on the Plain?' Aspirations and Limits of a Fastgrowing Small-Holder Agriculture in Central Tunisia," Cahiers Agriculture 24 (2015): 335-41; Mohamed Naouri, Tarik Hartani and Marcel Kuper, "Mobility of Rural Youth and New Forms of Saharan Agriculture (Biskra, Algeria)," Cahiers Agriculture 24 (2015): 379-386; Hassan Quarouch, Marcel Kuper, and Caroline Lejars, "Putting the Language of Institutions to Good Use: Farming Careers of Young Rural Unemployed University Graduates in Morocco's Saïss Region," Cahiers Agriculture 24 (2015): 349-356.

71 Abdellaoui EH, Kadiri Z, Kuper M, Quarouch H, 2015. Composer avec l'État : voies d'engagement des jeunes diplômés dans l'agriculture au Maroc. Cahiers Agricultures (2015) 24 : 356-362; Quarouch, Kuper and Lejars, "Putting the Language of Institutions to Good Use."

Kadiri and Errahj, "Leadership Rural au Maroc." 
grassroots organisations. As such, they contribute to the re-negotiation of the socio-political order at the local level. ${ }^{73}$

In sum, the economic and socio-political basis of the old rural social contract is eroding due to changes in use and access of natural resources linked to overexploitation and climate change; highly selective agricultural policies, which favor a particular kind of 'modern' agricultural development, which happens at the expenses of small scale farmers further marginalizing them and exacerbating socio-economic inequalities in terms of resources use and access; and finally the emergence of young rural leaders and the active role of young rural people in the development of their territory, challenging existing redistributive structures. The combination of these three factors gradually transforms the social rural contract and the links of dependency between the 'notables', controlling the countryside, and the state. It is interesting to note that whereas the former rural social contract was imposed from above, its redefinition is now mainly occurring from 'below'.

\section{Conclusion and Perspectives: The Re-negotiation of the Rural Social Contract}

In the MENA region, the social contract, which has been the basis for the relationships and bargains between rulers and populations since colonial times, is undergoing major changes. The questioning of its legitimacy, expressed elsewhere in the upheavals following 2011, currently leads to a renegotiation of the contract. In the context of the debates around a 'new social contract,' the present article argues for a different and differentiated perspective on rural areas, which have thus far been neglected in related research. The authors have coined the term of a 'rural social contract' to highlight the specific dynamics at work with respect to the political economy in the Maghreb's rural regions. Here, control over water and land resources have historically played and do still continue to play an important role for the political economy and related networks of privilege. The inadequate distribution of economic benefits from the use of these resources has favoured a selective development that privileged particular population groups and regions while neglecting others. However, today, the sensitive balance between the profitable use of resources for a minority and political control over the marginalized majority of the rural population has eroded. The authors illustrated how three trends contribute to modify

\footnotetext{
73 Zakaria Kadiri, Mohamed Tozy, Mohamed Mahdi M. Jeunes fellahs en quête de leadership au Maroc. Cahiers Agricultures (2015) $24: 428-434$.
} 
the very basis of the rural social contract, namely (a) ecological degradation and environmental change, (b) agricultural policies reinforcing marginalization and (c) the emergence of new rural actors challenging established social orders.

The analysis of these changes highlights the necessity and ongoing nature of a renegotiation of the rural social contract with respect to its economic basis, its legitimacy and the parties having a say on its design. The economic basis of the rural social contract is changing as gains from the exploitation of water and land are distributed to ever fewer beneficiaries and as agricultural value creation is increasingly monopolized due to environmental degradation and concentration of access to land, water and public subsidies. However, the analysis of the third trend - the emergence of new rural actors - also shows that this phenomenon is not merely a reinforcement of existing clientelistic networks. In contrast, new young actors emerge in the rural areas and bring in different resources (education, mobility, knowhow...) than those available to the previous generation, which allow them to have a greater stake in the renegotiation of the social contract. They partly suffer from the effects of agricultural policies privileging large agricultural entrepreneurs, but are also able to seize related opportunities arising, for example, when new subsidies are made available. Moreover, their involvement in a number of development activities confers them a different status than their parents mostly had: they are now additionally actively engaged in non-agricultural issues and thereby quickly participate in redefining and negotiating political and social influence, at least at local levels.

The example of the new rural actors points to another feature of the social contract under negotiation: the populations' active claim for and involvement in change. As one Moroccan observer from civil society notes, a fundamental shift in the relationship between citizens and state is currently happening: "It is the first time that a part of the population has held the view that the welfare and realisation of the potential of individuals and the community has to be achieved through the state and not outside of the state. It is the first time that the idea of a contract of equality, a mutual relationship between state and society has been mooted, in place of the unilateral contract that previously prevailed. ${ }^{\prime 4}$

Our analysis shows that the old social contract is transforming due to the decline of its socioeconomic and political basis. This article highlights how,

74 Translation by the authors. See AEF, "L'Etat Marocain: les Symboles ou le Contrat Social?" Blog NodeMaroc, http://nodebasic.drupalgardens.com/content/letat-marocain-les -symboles-ou-le-contrat-social. 
although small scale/family farmers face increasing exclusion and inequalities in terms of access to natural resources, in particular the younger generation of farmers are not passive victims waiting for the state to change their socioeconomic situation. Instead, they are innovative, well-educated and highly mobile people who carefully negotiate social structures and in doing so slightly re-interpret the social order and contribute to the emergence of a new social contract.

Public policies also evince political decision-makers' awareness of the weaknesses of the old social contract and of necessary adjustments. While agricultural policies and land/water monopolization continue to reinforce the marginalization of the majority of rural residents, the state has also aimed to mitigate the negative socio-economic effects of development in order to maintain a minimum level of social cohesion in the aftermath of the 'Arab Spring.' Within and beyond agricultural policies, this phenomenon materializes in two ways. First, the state has tolerated illegal practices like groundwater abstraction, extension of irrigated areas, and unpaid water bills. ${ }^{75}$ Second, the state has increased public wages and employment, food and energy subsidies, and public works since 2011 in the region to demonstrate its commitment to social justice. ${ }^{76}$ Its tolerance of a certain degree of criticism and support for local development initiatives also serve the same objective. In terms of the social contract, the formerly strict model of 'strong socioeconomic support in exchange for no political liberty' has changed to 'less socioeconomic benefits in exchange for limited freedom of action for local development initiatives.'

The structural problems created by a social contract which benefits only a minority of the population while excluding the rest have only partly been alleviated by the state's ad-hoc measures. This situation is not sustainable in the medium term and is even less sustainable in the long run. It is neither sustainable from an economic point of view, since public budgets are already overstretched, nor from a socio-political perspective, since the populations' fundamental concerns are not addressed and dissatisfaction persists. Finally, the critical deterioration of the environment and especially of already scarce water resources shows that the current practices are not sustainable from an environmental point of view either.

While a more equitable allocation of resources is a key part of a new, more egalitarian social contract, such an approach would not be sustainable in the

\footnotetext{
75 Kuper et al., "Liberation or Anarchy?"; Nicolas Faysse et al., "Formulation and Implementation of Policies to Deal with Groundwater Oversue in Morocco: Which Supporting Coalitions?" Irrigation and Drainage 61 (2012): 126-134.

$7^{6}$ Escribano, "A Political Economy Perspective on North Africa's Transitions."
} 
long term without adequate consideration for environmental sustainability. The analysis of the rural social contract shows that it is an important foundation of local power relations and patterns of resource use. Consequently, more egalitarian power relations and access to development in the rural areas can only be achieved if agricultural and regional development policies start addressing these inequalities in order to pave the way for a new social contract. 